\title{
INTESTINAL BACTERIAL PATHOGENS AND RISK FACTORS LEADING TO BACTERIAL DIARRHEA IN CAMEL CALVES IN SELECTED DISTRICTS OF AFAR NATIONAL REGIONAL STATE, NORTH EAST ETHIOPIA
}

\author{
MU-UZ GEBRU, F. ZERU, N. KUMAR* \\ A. TASHEW ${ }^{1}$ AND D. MERESA ${ }^{2}$ \\ College of Veterinary Medicine \\ Mekelle University, Mekelle, Ethiopia
}

To investigate intestinal bacterial pathogens and characterization of Escherichia coli isolates besides assessing management as well as herd and calf-level risk factors associated with camel calf diarrhea, a cross-sectional study was conducted in selected districts of Afar region, Ethiopia. A total of 384 fecal swabs were collected from diarrheic, convalescent and apparently healthy camel calves aged 12 months or younger and processed using standard conventional and molecular assays. The risk factors were assessed during sample collection using questionnaire survey and observational assessment. Out of the 384 camel calves examined, $\mathbf{5 9 . 3 8 \%}$ were found harboring one or more bacteria at varying levels. Salmonella (31.6\%), E. coli $(28.2 \%)$ and Klebsiella pneumoniae $(22.2 \%)$ were the predominant bacterial species isolated from the gastro intestinal tract (GIT) of apparently healthy calves. On the other hand, E. coli $(58.5 \%)$, Salmonella $(17.1 \%)$ and Enterococcus $(\mathbf{1 4 . 6 \%})$ were the most frequently encountered bacterial species in the diarrheic calves. Analysis of the questionnaire data revealed inconsistency in colostrum feeding, poor calf barn sanitation and health management. Age and colostrum feeding were the major risk factors associated with bacterial isolation and occurrence of calf diarrhea. Accordingly, young calves (0-3 months old) that didn't consume colostrum or received small amount of colostrum were at a significantly high risk of being affected with diarrhea $(\mathbf{P}<0.05)$. This study supports the assertion of E. coli 0157:H7, Salmonella enterica (gp3B) and Enterococcus feculis as being the most important pathogens involved in camel calf diarrhea and have important public health implication. Majority strains of the bacterial pathogens were found susceptible to norfloxacin, amoxicillin and gentamicin but resistant to ampicillin and tetracycline in vitro.

Key words: Afar, Bacteria, Camel calf, Diarrhea, E. coli, Risk factor

Camel (Camelus dromedarius) is a primary livelihood asset in the arid and semi-arid

*Corresponding Author

${ }^{1}$ College of Agriculture and Natural Resources, Raya University, Maichew, Ethiopia

${ }^{2}$ College of Veterinary Medicine, Samara University, Samara, Ethiopia lands in Ethiopia. The pastoralists see camels as a security against drought, 
disease, and other natural disasters (Farah et al., 2004). Rearing of camels under traditional pastoral production systems is faced with several challenges. There is high morbidity and mortality rate of camel calves in the first few weeks of age which impairs both growth rate and replacement of the herd (Marce et al., 2010).

The main reason for $68 \%$ of the camel calf losses in Niger is diarrhea (Faye et al., 1997). However, Bada et al. (1992) stated that the morbidity of diarrhea could reach up to $80 \%$ to $90 \%$ with around $50 \%$ mortality. Diarrhea in camel calves is caused by the synergistic effect of predisposing factors, viz. poor management practices, no colostrum intake, bacteria i.e. Salmonella and Escherichia coli and viral infections by Rota and Corona virus. Furthermore, many of the infectious agents that cause calf diarrhea may pose considerable threat to humans.

The present study was, therefore, designed to investigate the intestinal bacterial pathogens, including E. coli isolates to access the risk factors associated with the occurrence of camel calf diarrhea and also to determine the antibiotic sensitivity pattern in selected districts of Afar region, Ethiopia.

\section{MATERIALS AND METHODS}

Description of the study area: The total geographical area of Afar Regional state is about $270,000 \mathrm{~km}^{2}$. It is geographically located between $39^{\circ} 34^{\prime}$ and $42^{\circ} 28^{\prime}$ East
Longitude and $8^{\circ} 49^{\prime}$ and $14^{\circ} 30^{\prime}$ North Latitude. This study was conducted in the selected pastoral and agro pastoral districts viz. Asayita, Dubti, Berehalle and Aba-Ala in Afar region. Afar regional state is characterized by an arid and semi-arid climate with low and erratic rainfall. The annual temperature and rainfall in the region is $30-50^{\circ} \mathrm{C}$ and $200-600 \mathrm{~mm}$, respectively. The camel population of the region is 865,811 (CSA, 2016/17).

Study design: Camel calves which were apparently healthy, convalescent and clinically infected with diarrhea at the time of sampling were used as a source of fecal samples. Special emphasis was put on mucous membranes, skin turgor test to check hydration status, inspection of the perianal area for any signs of diarrhea. A cross-sectional study design was conducted in selected pastoral and agro-pastoral districts of Afar region. The districts were considered based on camel population, previous outbreaks of camel calf GIT infection and access to infrastructure.

Sample size determination: The desired sample size for the study was determined considering a 50\% expected prevalence as there was no previous investigation about the prevalence of the bacterial pathogens in the study districts and a 95\% Confidence Interval $(\mathrm{CI})$ at $\pm 5 \%$ desired accuracy, the sample size was calculated as described by Thrusfield (2007).

$n=\frac{1.962 \times P \exp (1-P \exp )}{\mathrm{d}^{2}}$ 
Where, $\mathrm{n}=$ number of sample size, Pexp =expected prevalence, $\mathrm{d}^{2}=$ absolute precision (5\%), Accordingly, the calculated sample size was 384 .

Sample collection: Fecal samples were collected from the apparently healthy, diarrheic and convalescent camel calves aged 12 months or less and were of different sex. Status of the mucous membrane, skin turgor, inspection of the perianal area, inspection for suckling reflex and history were considered to categorize apparently healthy, convalescent and clinically infected cases. The labeled swabs for bacterial examination were placed in a separate sterile test tubes containing tryptone soya broth (Oxide, Hampshire, England), kept in an ice box. The samples were transported to the nearby Samara/ Mekelle Veterinary Research and Diagnostic Laboratories on the day of collection for immediate incubation at $37^{\circ} \mathrm{C}$ for 24 hours (OIE, 2008).

\section{Identification based on morphological, cellular and biochemical characteristics:}

The fecal samples were streaked over an identified petri-plates including nonselective medium (blood agar, nutrient agar), a moderately selective differentiated medium (MacConkey agar), a more selective differentiated medium xyloselysine-decarboxylate(XLD) agar, eosin methylene blue (EMB) agar, brilliant green (BG) agar, a broth enrichment and an additional plate medium of choice (Oxide, Hampshire, England).

Single colony from different colony types of the positive cultures was sub-cultured on blood agar (Oxide, Hampshire, England) plates so as to obtain a pure culture for further analysis. The colonies were characterized and registered with their respective colony morphology. The pure cultures were subjected to Gram's staining to study staining reaction and cellular morphology under light microscope, at 100X magnification. Gram-negative bacteria were sub-cultured on MacConkey agar plates for further analysis (Quinn $e t$ al., 1994). Primary identification of the bacteria was performed using colony morphology, Gram reaction, cellular morphology, catalase and oxidase tests as well as growth on MacConkey, EMB, XLD and BG agar (Oxide, Hampshire, England) of the pure colony (Duerden et al., 1998). Pure cultures of single colony type were subjected to a series of secondary biochemical tests for final identification as indicated in (Quinn et al., 1994).

Fatty acid analysis using BiologMicrostation identification system: Pure isolates of $E$. coli and other bacterial species (based on biochemical tests) were prepared for Biolog-Microstation identification system (Biolog, California, USA) which is the latest molecular identification technique based on each microbial species surface 
fatty acid substrates, at Ethiopian Institute of Biodiversity. The colonies of bacterial species were inoculated on the Biolog Universal growth agar with $5 \%$ sheep blood and incubated at $37^{\circ} \mathrm{C}$ for $24 \mathrm{hrs}$. Subculturing was done using the same culture media to have pure culture colonies before identification was done.

Bacterial suspension was prepared from the grown pure culture colonies with an appropriate level of bacterial density, as recommended in the protocol of the instrument. The suspension was inoculated into Biolog micro plates aseptically. Then the micro plates were loaded into the Omnilog and incubated at $37^{\circ} \mathrm{C}$ for $24 \mathrm{hrs}$ (Omnilog user guide, 2008). Finally, the micro plates were read by the Omnilog identification system and the bacterial species were identified using the inbuilt Biolog database. E coli O157:H7 was confirmed using this technique.

Antibiotic susceptibility test: The pure bacterial colonies selected for antibiotic susceptibility test were cultivated on a MacConkey and blood agar medium under optimal incubation conditions to obtain a fresh overnight grown culture. A number of distinct colonies (3-5 morphologically similar colonies) were collected from the fresh grown plate culture and transferred to a tube containing 4-5 mL sterile distilled water. The suspension was mixed gently until turbidity corresponding to 0.5 McFarland standard is reached to obtain a homogeneous suspension and then poured onto Mueller-Hinton agar plate. After the inoculum on the plate was dried, antibiotic disks were distributed over the surface of the inoculated plates at equal distance from each other using sterile forceps. The disks were gently pressed onto the agar to ensure firm contact and then incubated for $24 \mathrm{hrs}$ at $37^{\circ} \mathrm{C}$.

After 24 hrs, the diameters of the zones of complete inhibition around the disks were measured to the nearest whole size from the back of the plate using a caliper. Complete inhibition zone margins were read as the area showing no obvious microbial growth detected by the unaided eye. It was read again after $48 \mathrm{hrs}$ of incubation if the isolates were not sufficiently grown. Every test was conducted two fold and then an average of the two results was taken as a final outcome. Growth inhibition zones were interpreted according to the manufacturer's (Oxoid antibiotic disks) recommendation and clinical and laboratory standards institute (CLSI, 2005).

Assessment of risk factors for calf diarrhea: Management as well as herd and camel calf-level risk factors associated with camel calf diarrhea were observed and assessed during sample collection. The questionnaire addressed the major risk factors including colostrums feeding, first colostrum feeding time, age, sex, hygiene and sanitation of calf pens and disease control measures practiced in the herd. The 
associations between calf diarrhea and the risk factors were calculated using chisquare at $95 \%$ confidence interval.

\section{Data processing and statistical analysis:}

The data obtained from the study were entered into Microsoft Excel 2007 spread sheet and transferred to SPSS ${ }^{\circledR}$ Version 20 software for statistical analysis. The results were summarized using descriptive statistics. Percentages were used to express the relative abundance of each genera/ species to the total number of isolates. Furthermore, chi-square test was computed so as to observe the relationship between the variants. P-value of $<0.05$ was considered indicative of a statistically significant difference.

\section{RESULTS}

Health status of camel sampled: Out of the 384 camel calves sampled from all study districts, $196(51.0 \%)$ were apparently healthy at the time of sampling and 162 (42.2\%) were clinically diseased exhibiting clinical signs viz. frequent passage of loose faeces (semi solid to watery feces with yellow greenish color mixed with mucous or blood flakes), soiling of rear quarter, decreased skin turgor, pale mucous membranes, sunken eyeballs, fever, depression, anorexic and loss of weight. The frequency of defecation also varied from 4 to 9 times per day. The remaining $26(6.8 \%)$ of the camel calves were convalescent.
Isolation and identification of bacterial species: Out of 384 fecal specimens/rectal swabs, a total of 311 isolates representative of different genera and species were identified from all study areas, namely, Asayita, Dubti, Ab-Ala and Berehale. The bacterial isolates constituted Salmonella, Enterococcus, Klebsiella, Staphylococcus spp and E. coli (Table 2) and the proportion of camel calves harboring E.coli was considerably high. More than one bacterial species was isolated from $39(24.07 \%), 26$ $(13.27 \%)$ and $10(38.46 \%)$ fecal samples collected from the diarrheic convalescent and healthy camel calves respectively. The most prevalent mixed isolates were Enterococcus with Klebsiella 18(24\%) followed by Salmonella with E. coli 14 $(18.7 \%)$ in diarrheic calves. Details of the mixed isolates are indicated in Table 1. On the other hand, only one bacterial isolate was identified out of the fecal samples investigated from 81 (50.0\%) diarrheic, 64 (32.65\%) apparently healthy and 7 (26.92\%) convalescent camel calves.

Bacterial species: In the present study different bacterial species were isolated from the GIT of all apparently healthy, convalescent and diarrheic camel calves. Salmonella, 37 (31.6\%) and E. coli, 33 (28.2\%) were the leading bacterial species isolated from the GIT of apparently healthy camel calves. Whereas, E. coli, $10(33.3 \%)$ and Salmonella, 9 (30.0\%) were the most frequently encountered bacterial isolates in 
the GIT of convalescent camel calves (Table 1). Rectal swabs collected from the camel calves with signs of GIT infection revealed that there was a high prevalence of E.coli which accounted for 96 (58.5\%) of the total bacterial isolates followed by
Salmonella and Enterococcus species each contributing for $28(17.0 \%)$ and $24(14.6 \%)$ of the total bacterial count, respectively. The further bacterial isolates and their absolute/relative abundance are presented on Table 1.

Table 1. Bacterial species isolated from the gastro-intestinal tract of camel calves

\begin{tabular}{lcccc}
\hline Bacteria species & \multicolumn{4}{c}{ Health status of camel calves } \\
\cline { 2 - 5 } & Diarrheic N (\%) & Convalescent N $(\boldsymbol{\%})$ & Healthy N (\%) & Total N (\%) \\
\hline Escherichia coli & $96(58.5 \%)$ & $10(33.3 \%)$ & $33(28.2 \%)$ & $139(44.7 \%)$ \\
Salmonella spp. & $28(17.1 \%)$ & $9(30.0 \%)$ & $37(31.6 \%)$ & $74(23.8 \%)$ \\
Klebsiella pneumoniae & $10(6.0 \%)$ & $5(16.0 \%)$ & $26(22.2 \%)$ & $41(13.2 \%)$ \\
Enterococcus spp. & $24(14.6 \%)$ & $0(0 \%)$ & $15(12.8 \%)$ & $39(12.5 \%)$ \\
Staphylococcus aureus & $6(3.6 \%)$ & $6(20.0 \%)$ & $6(5.1 \%)$ & $18(5.8 \%)$ \\
\hline Total N (\%) & $\mathbf{1 6 4}(\mathbf{1 0 0})$ & $\mathbf{3 0}(\mathbf{1 0 0})$ & $\mathbf{1 1 7}(\mathbf{1 0 0})$ & $\mathbf{3 1 1}(\mathbf{1 0 0})$ \\
\hline & & Mixed bacterial isolation & \\
En+E & $18(24 \%)$ & $2(2.7 \%)$ & 0 & $20(26.7)$ \\
S+E & $14(18.7 \%)$ & $1(1.3 \%)$ & $1(1.3 \%)$ & $16(21.3 \%)$ \\
En+S & $7(9.3 \%)$ & $3(4 \%)$ & 0 & $10(13.3 \%)$ \\
SA+S+E & 0 & $4(5.3 \%)$ & 0 & $4(5.3 \%)$ \\
SA+K & 0 & 0 & $9(12 \%)$ & $9(12 \%)$ \\
K+S & 0 & 0 & $8(10.7 \%)$ & $8(10.7 \%)$ \\
En+K & 0 & 0 & $8(10.7 \%)$ & $8(10.7 \%)$ \\
\hline Total N(\%) & $\mathbf{3 9}(\mathbf{1 0 0})$ & $\mathbf{1 0}(\mathbf{1 0 0})$ & $\mathbf{2 6}(\mathbf{1 0 0})$ & $\mathbf{7 5}(\mathbf{1 0 0})$ \\
\hline
\end{tabular}

En: Enterococcus, E: E.coli, S: Salmonella, SA: Staphylococcus aureus K: Klebsiella

Table 2. Prevalence of individual enteric bacterial spp.

\begin{tabular}{lcc}
\hline Bacterial species & Number of isolates & Prevalence (\%) \\
\hline Escherichia coli & 139 & 60.96 \\
Salmonella spp. & 74 & 32.46 \\
Klebsiella pneumoniae & 41 & 17.98 \\
Enterococcus spp. & 39 & 17.11 \\
Staphylococcus aureus & 18 & 7.89 \\
\hline
\end{tabular}


Table 3. Prevalence of enteric bacterial isolation in relation to host related risk factors and management

\begin{tabular}{|c|c|c|c|c|c|c|}
\hline \multicolumn{2}{|c|}{ Risk factors } & $\begin{array}{l}\text { No of calves } \\
\text { examined }\end{array}$ & \multirow{2}{*}{$\begin{array}{c}\text { No of calves } \\
\text { positive }\end{array}$} & \multirow{2}{*}{$\begin{array}{c}\begin{array}{c}\text { Prevalence } \\
(\%)\end{array} \\
64.89\end{array}$} & \multirow{2}{*}{$\begin{array}{c}\text { Chi-square } \\
11.4412\end{array}$} & \multirow{2}{*}{$\begin{array}{r}\text { P-value } \\
0.010\end{array}$} \\
\hline$\overline{\text { Age }}$ & $0-3$ & 188 & & & & \\
\hline (Months) & $4-6$ & 80 & 49 & 61.25 & & \\
\hline & $7-9$ & 81 & 35 & 43.21 & & \\
\hline & $10-12$ & 35 & 22 & 62.86 & & \\
\hline & Total & 384 & 228 & 59.38 & & \\
\hline \multirow{3}{*}{ Sex } & Male & 124 & 68 & 54.84 & 1.5624 & 0.211 \\
\hline & Female & 260 & 160 & 61.54 & & \\
\hline & Total & 384 & 228 & 59.38 & & \\
\hline \multirow{4}{*}{ Health status } & Diarrheic & 162 & 120 & 74.07 & 28.5197 & 0.000 \\
\hline & Convalescent & 26 & 17 & 65.38 & & \\
\hline & Healthy & 196 & 91 & 46.43 & & \\
\hline & Total & 384 & 228 & 59.38 & & \\
\hline \multirow{4}{*}{$\begin{array}{l}\text { Colostrum } \\
\text { feeding }\end{array}$} & Sufficient & 119 & 58 & 48.74 & 8.3471 & 0.015 \\
\hline & Small amount & 159 & 100 & 62.89 & & \\
\hline & Not at all & 106 & 70 & 66.04 & & \\
\hline & Total & 384 & 228 & 59.38 & & \\
\hline \multirow{4}{*}{$\begin{array}{l}\text { First } \\
\text { colostrum } \\
\text { feeding time }\end{array}$} & Before $6 \mathrm{hrs}$ & 151 & 80 & 52.98 & 4.5156 & 0.105 \\
\hline & After $6 \mathrm{hrs}$ & 126 & 78 & 61.90 & & \\
\hline & Not at all & 107 & 70 & 65.42 & & \\
\hline & Total & 384 & 228 & 59.38 & & \\
\hline
\end{tabular}

Table 4. Biolog-Omnilog identification and characterization of bacterial isolates

\begin{tabular}{lcc}
\hline Type of bacterial species & Number & $\begin{array}{c}\text { \% of identified } \\
\text { bacterial species }\end{array}$ \\
\hline E. coli O157:H7 & 26 & 6.77 \\
Enterococcus feculis & 8 & 2.08 \\
Serratiaodorifera & 3 & 0.78 \\
Salmonella enterica $(\mathrm{gp} 3 \mathrm{~B})$ & 15 & 3.91 \\
\hline
\end{tabular}


Table 5. The results of antibiotic susceptibility tests of bacterial isolates from the GI tracts of camel calves

\begin{tabular}{lcccccccccc}
\hline \multirow{2}{*}{ Bacterial species } & & \multicolumn{8}{c}{ \% of strains sensitive to the antibacterial agents } \\
\cline { 3 - 11 } & & AMP & E & K & NOR & TE & C & S & CN & AMO \\
\hline Salmonella & 15 & 20 & 40 & 66.7 & 86.7 & 6.7 & 73.3 & 40 & 80 & 73.3 \\
E. coli & 15 & 33.3 & 26.7 & 40 & 80 & 0 & 60 & 86.7 & 100 & 53.3 \\
K. pneumoniae & 8 & 0 & 62.5 & 25 & 75 & 37.5 & 50 & 100 & 87.5 & 62.5 \\
Enterococcus & 15 & 26.7 & 20 & 40 & 53.3 & 33.3 & 46.7 & 20 & 60 & 73.3 \\
S. aureus & 8 & 25 & 6.7 & 37.5 & 75 & 0 & 50 & 37.5 & 87.5 & 25 \\
\hline
\end{tabular}

$\mathrm{N}=$ Number of isolates tested, $\mathrm{AMP}=$ Ampicillin, $\mathrm{E}=$ Erythromycin, $\mathrm{K}=$ Kanamycin, NOR= Norfloxacin, $\mathrm{TE}=$ Tetracyclin, $\mathrm{C}=$ Chloramphenicol, $\mathrm{S}=$ Streptomycin, $\mathrm{CN}=$ Gentamicin, $\mathrm{AMO}=\mathrm{Amoxicillin}$

Table 6. Occurrence of calf diarrhea in association with colostrum feeding, first colostrum feeding time, sex and age groups as risk factors

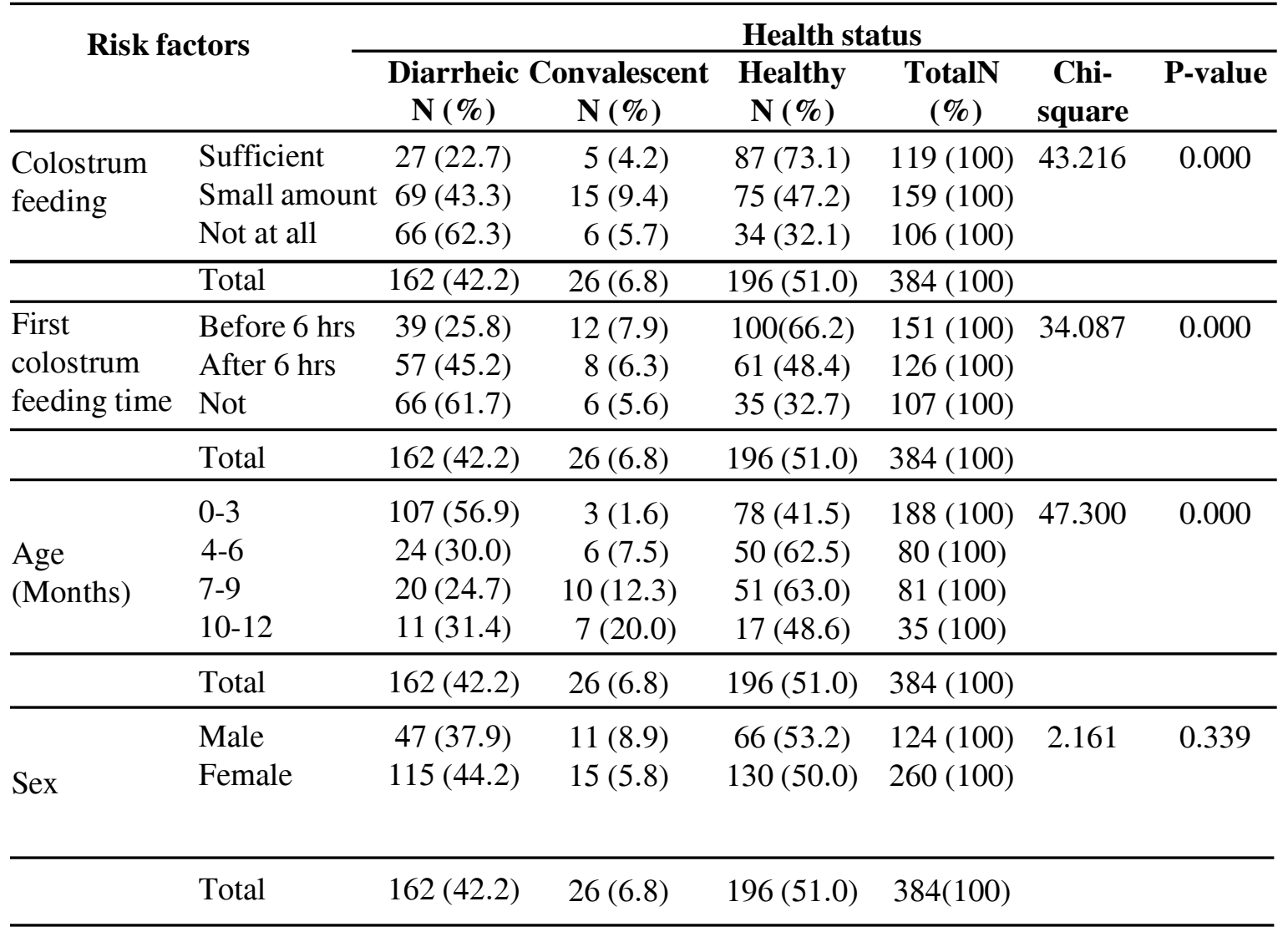


There was no significant difference $(\mathrm{P}>0.05)$ in infection by bacteria between male and female camel calves (Table 3 ). However, age, health status and colostrum feeding were found to be significant factors for the prevalence of GI bacteria $(\mathrm{P}<0.05)$, with bacteria being detected more frequently in diarrheic calves aged $0-3$ months that didn't consume colostrum (Table 3).

\section{Identification of bacterial isolates using Biolog-Omnilog identification system:} Four different species [E. coli O157:H7, Enterococcus feculis, Serratia odorifera and Salmonella enterica (gp3B)] were identified in calf diarrhea (Table 4).

\section{Antibiotic sensitivity pattern of bacterial isolates: The antibiogram profile of Salmonella strains indicated a marked susceptibility to norfloxacin, amoxicillin and gentamicin with $>73.3 \%$ inhibitory activity and highly resistant to ampicillin and tetracycline (Table 5). Most of the strains of E. coli have shown a high level of sensitivity to gentamicin and norfloxacin. They were poorly sensitive to erythromycin, ampicillin and kanamycin. Streptomycin, gentamicin and norfloxacin were the drugs revealed high sensitivity to most of the strains of $K$. pneumoniae. On the other side ampicillin and kanamycin were the least effective drugs. Gentamicin was the most effective drug against $S$. aureus with $87.5 \%$ growth inhibition. The bacteria resisted the action of tetracycline. Multidrug resistance (MDR) was also}

observed in most bacterial species (Table 5).

Questionnaire survey and observational assessment: There was statistically significant association between the occurrence of calf diarrhea and colostrum feeding, time of colostrum feeding and age groups. Accordingly, young calves (0-3 months old) that didn't consume colostrum or received small amount of colostrum late in their life were at a significantly high risk of being affected with diarrhea $(\mathrm{P}<0.05)$ (Table 6).

\section{DISCUSSION}

Diarrhea in young animals is a complex, multi-factorial disease involving the environment, management, nutritional factors besides involving infectious agents (Schoenian, 2006; Nasr and Meghawery, 2007; Shulaw, 2009). The major causes of infectious diarrhea in calves during the first months of life are bacteria, viruses and protozoa (Nidal, 2012) with camel calves that do not receive adequate colostrum are at greatest risk of developing diarrhea (Kuria et al., 2011).

In the present study, $59.38 \%$ of the 384 camel calves examined were found harboring one or more bacteria at varying levels. Young calves (0-3 months) of age were at a significantly high risk of being affected with diarrhea $(\mathrm{P}<0.05)$. The occurrence of calf diarrhea and isolation of the leading bacterial pathogens decreases 
as the age of the calves increased. This is mainly associated with the poorly developed immune system of the calves at the early stage of life which is not sufficient to fight against the disease causing agents (Darsema, 2008). Similar finding have been observed in the present study.

The current results revealed that $E$. coli and Salmonella spp. were commonly involved in causing diarrhea in young camel calves. A similar finding was also reported in Eastern Sudan (Salih et al., 1998). E. coli also responsible for causing diarrhea in human and animals (Osek, 2003), and is ubiquitous in the animal environment that is contaminated by feces (Jones, 1990).

E. coli was isolated from the GI tracts of diarrheic and apparently healthy camel calves at a rate of $58.5 \%$ and $28.2 \%$ respectively. Similarly, El-Hewairy et al. (2008) has reported the bacteria at a rate of $71.4 \%$ and $18.8 \%$ from diarrheic and apparently healthy camel calves respectively during their study on serotyping and molecular characterization of Escherichia coli isolated from diarrheic and in-contact camel calves from the district of Daraw city at Aswan Governorate.

Higher rate (66.0\%) has been reported by Salih et al. (1998) from Sudan while lower rate had been reported by Abubaker et al. (2006) and Zakia (2004) with prevalence rate of $27.3 \%$ and $22.6 \%$ respectively. Charles et al. (2003) stated that gaps in management includes inadequate nutrition, exposure to severe environment, insufficient attention to the newborn calf, or a combination of these are often involved in scours outbreaks. Calf diarrhea could be associated with qualitative or quantitative deficiency of the colostrum and may lead to rapid transmissions of the pathogenic $E$. coli strains (Quinn et al., 2005). Stoltenow and Vincent (2003) reported that the high risk of diarrhea in calves could be due to inadequate passive transfer of colostrum immunity.

Healthy ruminants such as cattle, sheep and goats are natural reservoirs of entero hemorrhagic $E$. coli (CHEC) especially $E$. coli O157:H7 (Blanco et al., 2003). Other domestic animals such as pigs, cats and dogs can also harbor these bacteria (Beutin et al., 1995). E. coli O157:H7 from diarrheic camel calves had also been reported in Egypt (El-Hewairy et al., 2008) and in healthy calves in Spain (Blanco et al., 2000).

The prevalence of Salmonella spp. and $K$. pneumoniae in camel calves suffering from diarrhea was found to be $17.1 \%$ and $6.0 \%$ respectively. Berrada et al. (2000) has documented $13.6 \%$ Salmonella spp. in one to ten weeks old diarrheic camel calves in the Moroccan Sahara. Salih et al. (1998) found $13 \%$ of Salmonella in diarrheic camel calves (birth till three months of age) in Sudan.

The animals that recover from Salmonella infections may become carriers for life, shedding organisms sporadically in their feaces (Radostitis et al., 2007). The 
infective dose and immunity status of the host determine the outcome of the infection (Venter et al., 1994). Animals infected with Salmonella can serve as a source of zoonosis through food born or direct contact routes (Mead et al., 1999). The isolation of $S$. aureus is of significance due to its role in mastitis in camels as well as contamination of meat and milk products (Colville and Berryhill, 2007). S. aureus is also an agent of severe diarrhea in humans (Adeyemi et al., 2003). Enterococcus spp. is a commensal bacterium found in the intestinal tracts of humans and other mammals (Bell and De Lacy, 1984). It is a common nosocomial infection (Borgmann et al., 2004).

The practice followed in the areas for colostrum feeding, first colostrum feeding time, calf pen sanitation and health management, among others, across the studied communities were not consistent. In this study, 47 of the 56 visited herds had very poor hygienic calf pens. After birth, calves are directly exposed to contaminated environments affected by presence of infected animals and overcrowding (Larson and Tyler, 2005; Larson et al, 2004). These factors usually work synergistically and increase the opportunity for increased duration of exposure to various types of pathogens.

Camelids lack placental transfer of immunoglobulins (Tibary and Anouassi, 2001). Camel calves therefore, rely on the immediate immunization soon after birth only through the colostrum, which has a very high concentration of antibodies. It is vital for the calf to suckle as soon and as much as possible (Nidal, 2012). The absence of colostrum intake is described as a contributing factor to camel calf diarrhea (Agab and Abbas, 1999). The calves which did not consume colostrum were at a higher risk of being affected with diarrhea $(\mathrm{P}<0.05)$ is in harmony with the above theory.

Most of pastoralists limit the colostrum access to the calf under the belief that it causes diarrhea. The wide spread practice of withholding the colostrum from the newborn calves had been reported to be certainly a critical factor in the frequently reported high calf mortality in pastoral production systems. Burgemeister (1975) observed that Tunisian herdsmen actively feed with colostrum those calves which fail to stand up soon after birth, because they consider the early intake as important.

If large amount of colostrum is ingested at once, the results into high amounts of ingested proteins cannot be completely absorbed and/or digested in the small intestine of the newborn and is passed on into the colon. These proteins are osmotically active causing water influx, may lead to the observed diarrhea in camel calves (Kaske, 1994).

A total of 100 grams of Immunoglobulin G1 (IgG1) needed to be fed to calf within 12-24 hours after birth (Tibary and Anouassi, 2001). Newborn camel calves should receive $10 \%$ of their body weight 
in colostrum, preferably within the first 12 hours after birth, with half of this amount given in the first six hours after birth.

The finding that delayed colostrum intake (later than 6 hours of age) associated with high risk of diarrhea was in agreement with other reports. Olsson et al. (1993) has reported that each hour of delay in colostrums ingestion in the first 12 hours of age increased the chance of a calf becoming ill by $10 \%$. Sixty one percent of colostral immunoglobulin containing 80 $\mathrm{mg} / \mathrm{mL}$ of $\mathrm{IgG}$ was found to be absorbed in six hours and decreases sharply, thereafter (Matte et al., 1982). The first six hours after birth is a critical period in which maximum absorption of colostral immunoglobulin takes place.

If the calves are not able to suck by themselves within 12 hours after birth, absorption of IgG after this time decreases significantly (Nidal, 2012). The calves which after birth cannot stand up by themselves made to stand and led to the udder. If, despite all efforts, a calf has not yet suckled in the first 6 hours after birth, the dam must be milked and the camel calf had to be given milk from a bottle. If the dam does not have enough colostrum, and no other camel colostrum is available, then cow or goat colostrum may be used as a substitute (Tibary and Anouassi, 2001).

Knowledge of local antimicrobial therapy in selecting the appropriate therapy and on the basis of in-vitro sensitivity tests is highly important (Caprioli et al., 2000). The majority of the bacteria were found susceptible to norfloxacin, amoxicillin and gentamicin but resistant to the action of ampicillin and tetracycline. Similar studies had been conducted in Nigeria by ElMahmood et al. (2009). Antibiotic resistance can be passed from one bacterial strain to another by gene transfer (Simjee and Gill, 1997) from commensals to pathogenic bacteria when both types of microorganism are present in animals. A large number of pastoralists medicate their animals themselves and that too a low dosage and not as per scientific rationale (Mu'uz et al., 2012). The resistance patterns were more evident to antibiotics frequently used like ampicillin and tetracycline. This finding is in agreement with that reported by Hariharan et al. (2004). Lower resistance to norfloxacin drug was also reported by other workers (Zhao et al., 2006; Lestari et $a l ., 2009)$. The emergence and spread of resistance can also be reduced through appropriate or careful use of antimicrobial drugs and increasing awareness among the population to the hazards of inappropriate antimicrobial use through public education campaign. Antibiotic sensitivity tests thus are highly useful and may be of enormous help to the clinician in the treatment of infections.

It may be concluded that diarrhea is considered as the major cause of morbidity and mortality in camel calves. Age and colostrum feeding were the major risk factors associated with bacterial isolation and occurrence of calf diarrhea. The 
demonstration of pathogenic bacteria in convalescent and healthy calves confirms the role of the calves as a reservoir and their faeces as a source of contamination for

\section{REFERENCES}

Abubaker M, Nayel MN, Fadlalla M and Abdel Rhma AO, 2006. The incidence of bacterial infections in young camels with reference to $E$. coli. The International Scientific Conference on Camels. May 1012-2006. Qassim University-College of Agriculture and Veterinary Medicine, pp 479-482

Adeyemi IG, Ikheloa AJ, Ogunleye AO and Orioke OO, 2003. Food borne pathogens found in local cheese sold at take-away food in Ibadan, Nigeria. Nigerian Vet J, 24(3): $86-89$

Agab H and Abbas B, 1999. Epidemiological studies on camel diseases in eastern Sudan, World Anim Rev, 92: 42-51

Bada R, Sani A, Kaboret Y, Oudar J and Akakpo AJ, 1992. Bacteria associated with infectious diarrhea in Niger. Dakar Médical, 37: 103-108

Bell RG and De Lacy KM, 1984. Heat injury and recovery of Streptococcus faecium associated with the souring of chub-packed luncheon meat. J Appl Bacteriol, 57: 229236

Berrada J, Bengoumi M and Hidane K, 2000. Diarrhées neonatales duchameleon dans les provinces sahariennes du Sud du environment, other animals and man.

Conflict of Interest: Authors declare that there is no conflict of interest regarding the present research work.

Maroc: études bactériologique, Revue Élev. Méd Vét Pays Trop, 53(2): 153-156

Beutin L, Geier D, Zimmermann S and Karch H, 1995. Virulence markers of Shiga-like toxin-producing $E$. coli strains originating from healthy domestic animals of different species. J Clin Microbiol, 33: 631-635

Blanco M, Blanco JE, Mora A, González EA and Blanco J, 2000. "Serotypes \& virulence genes of verocytotoxigenic $E$. coli (VTEC) isolated from cattle in Spain." In: Duffy, G.; Garvey, P.;Coia, J.; Wasteson, Y. andMcDowell, D.A. (Eds.), Verocytotoxigenic E. coli in Europe, 3. Pathogenicity andvirulence of verocytotoxigenic E. coli. Concerted Action CT98-3935. Teagasc, The National Food Centre, Dublin, pp 183

Blanco M, Blanco JE, Mora A, Rey J and Alonso JM et al., 2003. Serotypes, virulence genes, and intimin types of Shigatoxin (verotoxin)-producing Escherichia coli isolates from healthy sheep in Spain. J Clin Microbiol, 41: 13511356

Borgmann S, Niklas DM, Klare I, Zabel LT and Buchenau P et al., 2004. Two episodes of vancomycin-resistant Enterococcus 
faecium outbreaks caused by two genetically different clones in a newborn intensive care unit. Int J Hyg Environ Hlth, 207: 386-389

Burgemeister R, 1975. Elévage de Chameaux en Afrique du Nord. Eschborn, Germany, GTZ

Caprioli A, Busani L, Martel JL and Helmuth $\mathrm{R}$, 2000. Monitoring of antibiotic resistance in bacteria of animal origin: Epidemiological and microbiological methodologies. Int J Antimicrob Agents, 14: $295-301$

Charles L, StoltenowLL and Vincent MS, 2003. Citing Website. Calf scour: cause, prevention and treatment. Retreived on May, 2014 from URL. Available at: WWW.ag.adsu.edu./pubs/ansci/beet/ as776.pdf.

CLSI, 2005. Analysis and presentation of cumulative antimicrobial susceptibility test data. Approved guideline, $2^{\text {nd }}$ edn., CLSI document M39-A2, NCCLS, 940 West Valley Road, Suite 1400, Wayne Pennsylvania, pp 1809-1898

Colville JL and Berryhill DL, 2007. Hand Book of Zoonoses. Identification and prevention. Mosby Elsevier, Loius, Missouri 63146, USA, pp 249

CSA, 2016/17. Livestock Population of Ethiopia. Central Statistical Authority (CSA), Addis Ababa, Ethiopia

Darsema G, 2008. Major causes of calf mortality in dairy farms and two cattle ranches in western Amhara region, north western Ethiopia. Ethiop Vet J, 12(2): 5968

Duerden BI, Towner KJ and MageeJT, 1998. Isolation, description and identification of bacteria. In: Collier L, Balows A, Sussman M, editors. Topley and Wilson's Microbiology and Microbial Infections. Systematic Bacteriology. $9^{\text {th }}$ edn., Vol 2. London: Arnold, pp 65-84

El-Hewairy HM, Awad WS and Ibrahim AK, 2008. Serotyping and molecular characterization of E.coli isolated from diarrheic and in-contact camel calves. Egypt J Comp Path Clinic Path, 22 (1): 216-233

El-Mahmood AM, Isa $\mathrm{H}$, Mohammed A and Tirmidhi AB, 2009. Antimicrobial susceptibility of some respiratory tract pathogens to commonly used antibiotics. J Clin Med Res, 2: 135-142

Farah KO, Nyariki DM, Ngugi RK, Noor IM and Guliye AY, 2004. The Somali and the Camel: Ecology, Management and Economics. Anthropologist, 6: 45-55

Faye B, Meyer C and Marti A, 1997. Guide de l'élevage du dromadaire, Sanofi Santé Nutrition Animale, La Ballastiere BP126, 33501 Libourne, Cedex, France

Hariharan H, Coles M, Poole D and Page R, 2004. Antibiotic resistance among enterotoxigenic E.coli from piglets and calves with diarrhea. Canadian Vet J, 45: 605-606 
Jones TO, 1990. Escherichia coli mastitis in dairy Cattle. A review of the Literature. Vet Bull, 60: 205-220

Kaske M, 1994. Pathophysiologische Aspekte der neonatalen Kälberdiarrhoe. Tierärztl Umschau, 49: 336-348

Kuria SG, Tura I, Amboga S, Walaga HK and Lesuper J, 2011. The current status of camel (Camelus dromedarius) calf management among pastoral communities of northern Kenya. Livest Res Rural Dev, 23: 7

Larson RL and Tyler JW, 2005. Reducing calf losses in beef herds. Vet Clin North Am Food Anim Pract, 21: 569-584

Larson RL, Tyler JW, Schultz LG, Tessman RK and Hostetler DE, 2004. Management strategies to decrease calf death losses in beef herds. J Am Vet Med Assoc, 224: 4248

Lestari SI, Han F and Wang F, 2009. Prevalence and antimicrobial resistance of Salmonella serovars in conventional and organic chickens from Louisiana retail stores. J Food Prot, 72: 1165-1172

Marce C, Guatteo R, Bareille N and Fourichon C, 2010. Dairy calf housing systems across Europe and risk for calf infectious disease. Animal, 4: 1588-1596

Matte JJ, Girard CL, Seoane JR and Brisson GJ, 1982. Absorption of colostral immunoglobulin $\mathrm{G}$ in the newborn dairy calf. J Dairy Sci, 65: 1765-1770
Mead PS, Slutsker L, Dietz V, Mccaig LF and Griffin PM et al., 1999. Food related illness and death in the United States. Emerg Infec Dis, 5: 607-625

Mu'uz G, Tesfaye S, Genene T and Fufa D, 2012. Bacteriological studies on pneumonia in camels (Camelus dromedaries) in selected districts of Afar region, Ethiopia. Proceeding of the Annual Research Review Symposium, Samara University, Volume 1, pp 96-113

Nasr EM and Meghawery MA, 2007. Studies on diarrhea in calves with emphasis on the role of Clostridium perfringes and Escherichia coli. Res J Anim Vet Sci, 2: 28-33

Nidal ME, 2012. Camel neonatal diarrhea and its management. A thesis submitted in accordance with the requirements for $\mathrm{PhD}$ in veterinary medicine, Sudan University of Science and Technology, College of Graduate Studies, pp 56-65

OIE, Office International des Epizooties (2008): Manual for terestitial animal diseases

Olsson SO, Viring S, Emanuelsson U and Jacobsson SO, 1993. Calf diseases and mortality in Swedish dairy herds. Acta Vet Scand, 34: 263-269

OmniLog ${ }^{\circledR}$ Data Collection Software Identification System User Guide (2008)

Osek J, 2003. Multiplex PCR use for rapid identification of E. coli and genes 
encoding LT1, STM and EAST1 exotoxins. Medycyna Weternaryina, 59: 501-505

Quinn PJ, Carter ME, Markey B and Carter RG, 1994. Bacterial Pathogens: Microscopy, Culture, and Identification. In: Clinical Veterinary Microbiology. Wolfe Publishing, London, pp 21-80

Quinn PJ, Carter ME, Markey B and Carter RG, 2005. Clinical Veterinary Microbiology. $7^{\text {th }}$ edn., Elsevier Health Science Ltd., Philadelphia, USA, pp 222-224

Radostitis OM, Gay CC, Hinchcliff KW and Constable PD, 2007. Veterinary Medicine: A text book of diseases of cattle, horses, sheep, pigs \& goats. $10^{\text {th }}$ edn., Elsevier Scientific Publications, Saunders pp 2160

Salih O, Shigidi MT, Mohamed HO and Chang Y, 1998. The bacterial causes of camel-calf (Camelus dromedarius) diarrhea in eastern Sudan. Proceedings of the third annual meeting for animal production under arid conditions, United Arab Emirates University, 2: 132-137

Schoenian S, 2006. Diarrhea (scours) in small ruminants. In: Small ruminant Fact Sheet Series. University of Maryland Cooperative Extension, pp 1-4

Shulaw B, 2009. Management considerations to lower lamb mortalities. The Ohio State University: Sheep Team. http:// sheep.osu.edu./2009/01/13. Accessed 18/ $8 / 2014$
Simjee S and Gill MJ, 1997. Gene transfer, gentamicin resistance and enterococci. J Hosp Infect 36: 249-259

Stoltenow CL and Vincent LL, 2003. Citing Website. Calf scours: causes, prevention, and treatment. Fargo, North Dakuta. Retrieved on June, 2014 from URL. Available at: WWW.ag.adsu.edu./pubs/ ansci/beet/as77Pdf.

Thrusfield M, 2007. Veterinary Epidemiology. Survey $3^{\text {rd }}$ edn., Blackwell Science, UK, pp 1-332

Tibary A and Anouassi A, 2001. Retrospective study on an unusual form of ovario-bursal pathology in the camel (Camelus dromedarius). Theriogenology, 56: 415424

Venter BJ, Myburgh JG and Vanderwalt ML, 1994. Bovine Salmonellosis in: Infectious disease of livestock, Oxford University Press, Cape Town, Oxford, Newyork , pp 1104-1112

Zakia AM, 2004. The role of Clostridium perfringens in camel calf diarrhea in Sudan with special reference to the pathogenesis and pathological changes. $\mathrm{PhD}$ thesis, Sudan

Zhao S, McDermott PF, Friedman S, Abbott J and Ayers $\mathrm{S}$ et al., 2006. Antimicrobial resistance and genetic relatedness among Salmonella from retail foods of animal origin: NARMS retail meat surveillance. Food Borne Patho Dis, 3(1): 106-117 